\title{
Effect of cochlear implantation on language development and assessment of the quality of studies in this field: A systematic review
}

\author{
Soodeh Khoramian ${ }^{1}$, Zahra Soleymani*1, Nasrin Keramati ${ }^{1}$, Masoud Motasaddi Zarandy ${ }^{2}$ \\ Received: 13 Aug 2018 \\ Published: 7 Oct 2019
}

\section{Abstract}

Background: Cochlear implantation (CI) is an achievement that facilitates the acquisition of language skills in deaf children throughout the world. The use of this technology has a positive effect on all components of language acquisition (syntax, semantic, pragmatic, etc.). However, this positive impact is influenced by various factors. Understanding the strengths and weaknesses of studies on the development of language abilities can help improve these studies. Consequently, in the future, it will lead to the improvement of language rehabilitation in these children. Limited studies on children with CI in have been done so far. This article summarized the outcomes of scientific articles on the clinical efficacy of CI on Persian speaking children. This study also provided a clear picture of these studies by examining the quality of their methodologies and tools.

Methods: Articles indexed in Google Scholar, Web of Science, Medline, Scopus and Iranian databases (Danesh Gostar, Magiran, and SID) were searched using keywords "language," "Cochlear implant", "Persian/ Farsi" in English and Persian languages with "and/or". Original articles investigated on children younger than 13 years old with hearing impairment and CI were included.

Results: Five hundred and twenty-three articles were found based on the keywords. Among all of these, 485 were excluded due to the title and the abstract; we selected 38, of which 24 were repeated. Finally, 14 articles remained. We reviewed the articles based on the preferred reporting items for systematic review and meta-analysis (PRISMA) and checklist and Grading of Recommendations, Assessment, Development, and Evaluations (GRADE).

Conclusion: Similar to international studies, Persian speaking children with CI have slower language development than their peers with normal hearing, but they are better than their peers who use hearing aids. The results of reviewing on quality of the articles showed that the studies could not meet reasonable quality because of the lack of a standard test in different aspects of Persian language and the absence of patients' databanks. These results also can be used by other nationalities that recently have started surveys on children with CIs.

Keywords: Cochlear implant, Child, Language, Iran, Developmental language disorders, Persian

Conflicts of Interest: None declared

Funding: None

*This work has been published under CC BY-NC-SA 1.0 license.

Copyright $\odot$ Iran University of Medical Sciences

Cite this article as: Khoramian S, Soleymani Z, Keramati N, Motasaddi Zarandy M. Effect of cochlear implantation on language development and assessment of the quality of studies in this field: A systematic review. Med J Islam Repub Iran. 2019 (7 Oct);33:107. https://doi.org/10.47176/mjiri.33.107

\section{Introduction}

Hearing impairments is seen in 3.5 neonates out of

Corresponding author: Dr Zahra Soleymani, soleymaniz@sina.tums.ac.ir

1. Department of Speech Therapy, School of Rehabilitation, Tehran University of Medical Sciences, Tehran, Iran

2. Department of Cochlear Implant, Otorhinolaryngology Research Center, Amir Aalam Hospital, Tehran, Iran
1,000 live births (1). In Iran, it is considered to be $2-3$ in

$\uparrow$ What is "already known" in this topic:

- Previous studies showed progress of language skills, communication, and speech abilities in English-speaking children with hearing impairment after cochlear implantation (CI)

- There is no systematic review on Farsi-speaking children with CI

$\rightarrow$ What this article adds:

- Cochlear implant surgery is an effective way for the development of language skills in Persian -speaking children, as well as English-speaking children.

- Many other aspects of language such as pragmatics, semantics and several subcategories of grammar need to be studied in Persian speaking children with CI. 
1000 (2). Being deprived of hearing in children is a major challenge for learning and using language $(3,4)$. Language is an indispensable tool for social interaction. Speech and language are fundamental to the development of emotional and social skills in children. Literacy is a consequence of language development. Therefore, language impairment might lead to educational, social, and behavioral problems. Language is highly important for children as it paves the path to a wide range of training, culture, and job opportunities in the future. In addition, language is the primary predictor of learning capability in young children with severe to deep hearing impairment (5). For this reason, the main objective of the rehabilitation of children with hearing impairment is to achieve speech and language skills $(6,7)$.

The past few decades have been featured with outstanding advances in the potential of developing and utilizing language for children with severe to deep hearing impairment (3) and of these advances is the introduction of cochlear implant (CI) as one of the most effective hearing aids (8). Several studies all around the world have examined and compared different fields of languages in individuals with CI, normal individuals, and those using hearing aids. In general, the results of studies in this field have indicated that the pace of language development of the children using standard amplifiers such as hearing aid or touch amplifiers is one-half of the normal children (9-12). On the other hand, children with CI demonstrate capabilities almost identical with those of their normal peers at different linguistic levels (phonology, morphology, words, etc.) (13).

Recent years have witnessed notable advances in permanent CI technology so that many children, who had to rely only on sign language in the past, now can acquire language skills (14).

To search for more accurate and better research on the language system, the language was divided into its main components: form, content, and use (15). Form includes morphology, syntax, and phonology; content includes semantics, and use includes pragmatics (16). Many studies have been conducted on CI in Iran; however, sharing of linguistic studies in this field is rare. Most studies have been conducted on Persian language children in the field of voice, speech, communication and auditory skills of these children (17-25). Currently, clinical decision making in linguistic fields are pertinent to the studies in English speaking children.

The primary objective of this systematic review study is to survey studies performed on the Persian speaking children with CI that was compared with peers who use hearing aids and normal hearing $(\mathrm{NH})$ peers to estimate clinical efficacy of CI. Another objective of this study is to achieve a comprehensive point of view about the components (e.g., phonology, syntax, morphology, semantics, and pragmatics) of language in these children that need further study. Finally, a survey of the quality of the tools and methodology of these studies was used to identify the shortcomings. Hoping to address these deficiencies and improve quality in future studies in this area. In fact, our goals are to answer the following questions:
How does the language of children with hearing loss improve after cochlear implantation?

What are the specifications and features of studies on Persian children with CI?

The focus of studies on which components of language (e.g., phonology, syntax, morphology, semantics, and pragmatic) is less?

\section{Methods}

This systematic review was designed and carried out based on preferred reporting items for systematic review and meta-analysis (PRISMA), which is a checklist with 27 statements that ensures transparency of a systematic report (26). Articles were analyzed using a GRADE critical form (27).

The search strategy was performed according to Prisma. Research on Persian speaking children with CI was included. All articles in this field published up to 21/4/2018 and indexed in Danesh Gostar, SID -Which is a reliable Persian bank of scholarly articles published in Iran-, Google Scholar, Web of Science, MEDLINE via PubMed, Scopus, and publisher databases (Springer, Science Direct) were included. Additional articles were discovered by a monthly search update. Articles on speech therapy and audiology conferences were reviewed by a manual search. Multiple different combinations of the following keywords were used in the search queries: "language, cochlear implant, Persian, and Farsi, language development, grammar, vocabulary, morphology, syntax, pragmatic and reading" (in Persian and English) using "or/and" (Appendix 1). No time limitation was added to the search, and the articles were searched independently by two researchers, and the inconsistencies were solved by a third researcher. Inclusion criteria were participants' strategy, intervention, outcomes, and study design (PICOS), which are; children under 13 years of age with any degree of hearing loss (hearing aids or implants) and normal hearing(Participants), CI (Intervention), children with normal hearing / hearing aids (Control), study of the language including: vocabulary, semantics, syntax, pragmatics and reading (Outcomes) and randomized controlled trials, non-randomized controlled trials, cohort studies, and repeated measures(Study designs).

Only the studies on language development in Persian speaking children younger than 13 years old and with CI were examined.

Two researchers carried out the search task, so that titles and abstracts were examined first and then the fulltext of the articles that met the inclusion criteria entered the study. Finally, 38 out of 523 articles were selected and out of which 24 were excluded as they were repetitive. Hence, this study was carried out on 14 reminding articles (Fig. 1).

\section{Inclusion criteria}

1. Studies on Persian speaking children with CI.

2. Studies on one or more fields of language including morphology, syntax, phonology, semantics, and pragmatics.

All studies in the Persian/ Farsi and English language 


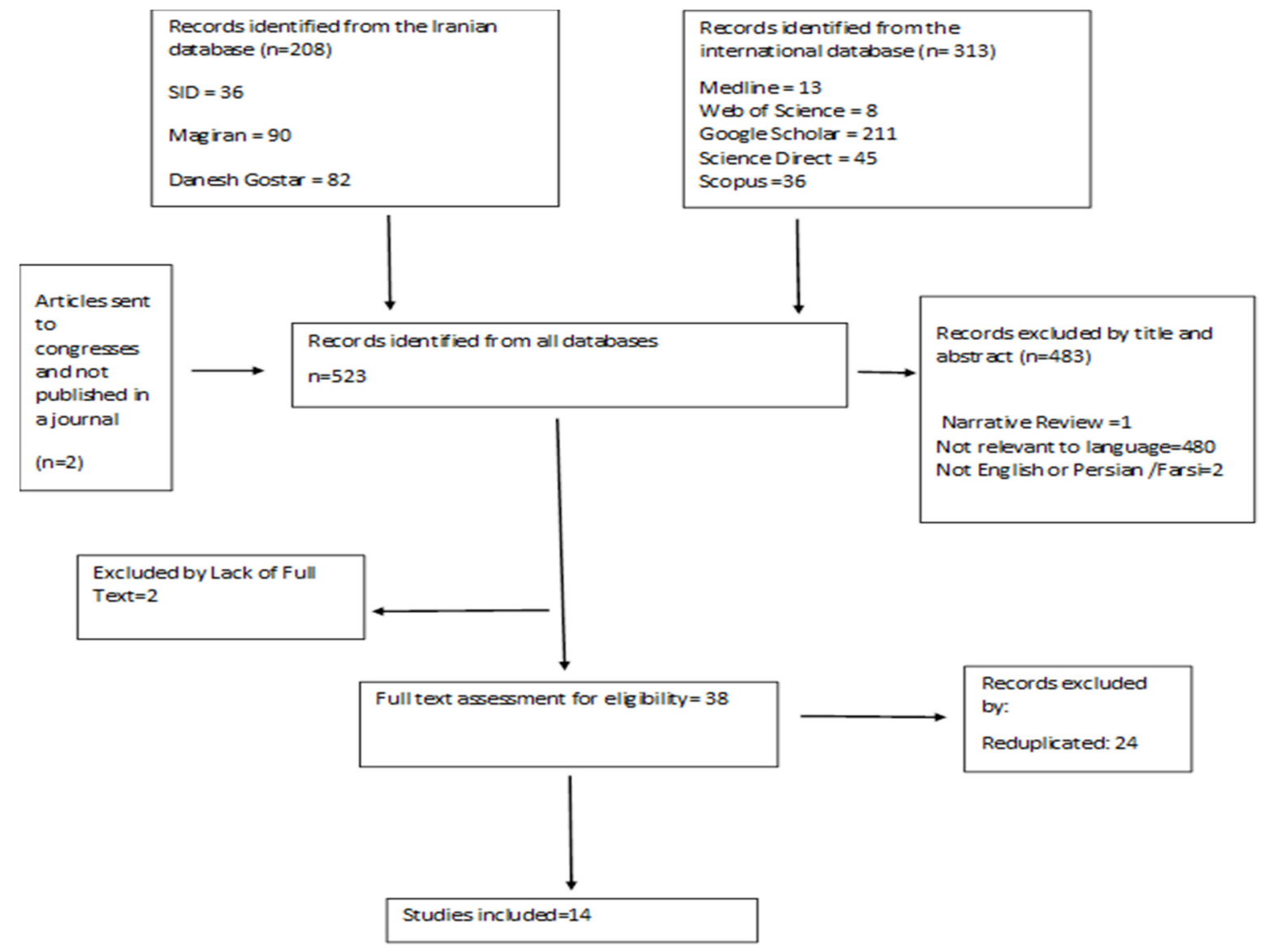

Fig. 1. Flow diagram of the systematic search and selection process of articles

were included in our review.

Studies on children with CI compared with normal children or children with hearing aids.

Exclusion criteria: Studies focused on CI comorbid with other disorders such as genetic and neuropathy disorders; Review articles; Studies focused only on acoustic aspects of speech; Studies on non-verbal communications; Studies focused on adult with CI; Studies without full text.

Each paper was screened and checked by two reviewers that had master in Speech and Language Pathologist.
Chance adjusted inter-rater agreement was calculated for agreement between two raters (Cohen's kappa =0.93) (28). Independently and probable disagreements were settled through discussion under the supervision of a third reviewer, who was Ph.D. of Speech and Language Pathology and an expert in the field.

Table 1 lists brief information of the articles including authors' names, year of publication, title, number of participants, statistical methods, tools, and the results of each paper.

Table 1. A summary of descriptive data from the articles with inclusion criteria

\begin{tabular}{|c|c|c|c|c|c|c|c|c|c|c|}
\hline & Study & Design & $\begin{array}{l}\text { Population/ } \\
\text { Sample } \\
\text { size (n) }\end{array}$ & Age & Randomization & $\begin{array}{c}\text { Target } \\
\text { (What studied) }\end{array}$ & $\begin{array}{c}\text { Data } \\
\text { collection }\end{array}$ & $\begin{array}{l}\text { Validity } \\
\text { and } \\
\text { reliability } \\
\text { stated }\end{array}$ & $\begin{array}{c}\text { Statistical } \\
\text { analysis } \\
\text { explained }\end{array}$ & Results \\
\hline 1 & $\begin{array}{l}\text { Weisi } \\
\text { et al., } \\
2013 \\
(29)\end{array}$ & $\begin{array}{l}\text { Cross- } \\
\text { sectional } \\
\text { study }\end{array}$ & $\begin{array}{c}12 \mathrm{CI} \text { and } \\
12 \\
\mathrm{HA}\end{array}$ & $\begin{array}{l}\text { Second } \\
\text { grades } \\
\text { student }\end{array}$ & NR & $\begin{array}{l}\text { Evaluation of } \\
\text { phonological } \\
\text { awareness among } \\
\text { children with } \\
\text { CI and children } \\
\text { with hearing aids }\end{array}$ & $\begin{array}{l}\text { phonological } \\
\text { subtests of NAMA } \\
\text { reading test }\end{array}$ & Yes & T- test & $\begin{array}{l}\text { Children with } \mathrm{Cl} \\
\text { have better per- } \\
\text { formance } \\
\text { than the children } \\
\text { with hearing aids } \\
\text { on phone. Non- } \\
\text { word reading tasks } \\
\text { weren't } \\
\text { significantly } \\
\text { different between } \\
\text { the two groups }\end{array}$ \\
\hline 2 & $\begin{array}{l}\text { Rahimi } \\
\text { et al., } \\
2013 \\
(30)\end{array}$ & $\begin{array}{l}\text { Cross- } \\
\text { sectional } \\
\text { study }\end{array}$ & $\begin{array}{c}30 \mathrm{CI} 30 \\
\mathrm{NH}\end{array}$ & $5-8$ years & NR & $\begin{array}{l}\text { Study of Linguis- } \\
\text { tic Skills of } \\
\text { Persian CI } \\
\text { and Normal Hear- } \\
\text { ing Children }\end{array}$ & $\begin{array}{lr}\text { Language, } & \text { Phono- } \\
\text { logical } & \text { Skills, } \\
\text { Semantic } & \text { Skill, } \\
\text { Syntactic } & \\
\text { Skill } & \end{array}$ & Yes & T-test & $\begin{array}{l}\text { Normal children } \\
\text { have better per- } \\
\text { formance } \\
\text { than CI in all } \\
\text { language skills }\end{array}$ \\
\hline
\end{tabular}


A systematic review of language development in children with cochlear implant

\begin{tabular}{|c|c|c|c|c|c|c|c|c|c|c|}
\hline & Study & Design & $\begin{array}{l}\text { Population/ } \\
\text { Sample } \\
\text { size (n) }\end{array}$ & $\overline{\text { Age }}$ & Randomization & $\begin{array}{c}\text { Target } \\
\text { (What studied) }\end{array}$ & Data collection & $\begin{array}{l}\text { Validity } \\
\text { and } \\
\text { reliabil- } \\
\text { ity } \\
\text { stated }\end{array}$ & $\begin{array}{l}\text { Statistical } \\
\text { analysis } \\
\text { explained }\end{array}$ & Results \\
\hline 3 & $\begin{array}{l}\text { Ghaemi } \\
\text { et al., } \\
2014(31)\end{array}$ & $\begin{array}{l}\text { Cross- } \\
\text { sectional } \\
\text { study }\end{array}$ & $\begin{array}{c}10 \mathrm{CI} \text { and } \\
10 \mathrm{NH}\end{array}$ & $\begin{array}{c}\text { Mean age } \\
\text { of } 5.5 \text { years }\end{array}$ & NR & $\begin{array}{l}\text { Evaluation of } \\
\text { comprehension } \\
\text { and using passive } \\
\text { verbs in children } \\
\text { with hearing loss } \\
\text { with CI and } \\
\text { normal children }\end{array}$ & $\begin{array}{l}\text { passive verb's } \\
\text { comprehension }\end{array}$ & Yes & T- test & $\begin{array}{l}\text { comprehension and using } \\
\text { passive verbs in normal } \\
\text { children is better } \\
\text { than CI }\end{array}$ \\
\hline 4 & $\begin{array}{l}\text { Mohseni } \\
\text { et al., } \\
2015(32)\end{array}$ & $\begin{array}{l}\text { Cross- } \\
\text { sectional } \\
\text { study }\end{array}$ & $\begin{array}{l}35 \mathrm{CI} \text { and } \\
35 \mathrm{NH}\end{array}$ & $\begin{array}{l}4-7 \\
\text { Years }\end{array}$ & $\begin{array}{l}\text { Yes } \\
\text { (Multistage } \\
\text { cluster) }\end{array}$ & $\begin{array}{l}\text { Study of Cochlear } \\
\text { Implanted Chil- } \\
\text { dren and Children } \\
\text { with Normal } \\
\text { Hearing Language } \\
\text { Development } \\
\end{array}$ & $\begin{array}{l}\text { scale of lan- } \\
\text { guage devel- } \\
\text { opment }\end{array}$ & Yes & $\begin{array}{c}\text { Pearson Correla- } \\
\text { tion Coefficient } \\
\& \\
\text { covariance } \\
\text { analysis }\end{array}$ & $\begin{array}{l}\text { CI children had high } \\
\text { scores in the scale of } \\
\text { language development, } \\
\text { but normal children have } \\
\text { better performance } \\
\text { than CI }\end{array}$ \\
\hline 5 & $\begin{array}{l}\text { Weisi et } \\
\text { al., } \\
2012(33)\end{array}$ & $\begin{array}{l}\text { Descript } \\
\text { ive - } \\
\text { analytic } \\
\text { study }\end{array}$ & $\begin{array}{l}24 \mathrm{CI} \text { and } \\
24 \mathrm{NH}\end{array}$ & $\begin{array}{l}\text { Second and } \\
\text { the } \\
\text { third } \\
\text { grades of } \\
\text { elementary }\end{array}$ & NR & $\begin{array}{l}\text { study of reading } \\
\text { skills between CI } \\
\text { and normal hear- } \\
\text { ing children in } \\
\text { second and third } \\
\text { grade } \\
\text { elementary }\end{array}$ & $\begin{array}{l}\text { NAMA read- } \\
\text { ing test }\end{array}$ & Yes & $\begin{array}{l}\text { T-test, linear } \\
\text { regression and } \\
\text { Pearson correla- } \\
\quad \text { tions }\end{array}$ & $\begin{array}{l}\text { normal children have } \\
\text { better performance } \\
\text { than CI in reading skills }\end{array}$ \\
\hline 6 & $\begin{array}{l}\text { Mahmoo } \\
\text { dabadi } \\
\text { et al., } \\
2014 \text { (34) }\end{array}$ & $\begin{array}{l}\text { Cross- } \\
\text { sectional } \\
\text { study }\end{array}$ & $\begin{array}{c}18 \mathrm{CI} \text { and } \\
18 \mathrm{NH}\end{array}$ & $\begin{array}{l}\text { Mean age } \\
\text { of } 5.5 \text { years }\end{array}$ & Yes & $\begin{array}{l}\text { Comparison of } \\
\text { phonological } \\
\text { awareness skills } \\
\text { between CI } \\
\text { and normal hear- } \\
\text { ing children }\end{array}$ & $\begin{array}{l}\text { auditory-visual } \\
\text { modality } \\
(2010) \text { and } \\
\text { visual modality }\end{array}$ & Yes & $\begin{array}{l}\text { Mann Whithney } \\
\text { \& Spearman } \\
\text { non-parametric } \\
\text { tests }\end{array}$ & $\begin{array}{l}\text { normal children have } \\
\text { better performance } \\
\text { than CI in both Visual - } \\
\text { Auditory and } \\
\text { Auditory phonological } \\
\text { awareness tests. }\end{array}$ \\
\hline 7 & $\begin{array}{c}\text { Rastegar- } \\
\text { ianzadeh } \\
\text { et al } 2014 \\
\text { (35) }\end{array}$ & $\begin{array}{l}\text { cross- } \\
\text { sectional } \\
\text { study }\end{array}$ & $\begin{array}{l}48 \mathrm{CI} \text { and } \\
30 \mathrm{NH}\end{array}$ & $70-95$ mon & NR & $\begin{array}{l}\text { Comparison of } \\
\text { phonological } \\
\text { awareness skills } \\
\text { between CI } \\
\text { and normal hear- } \\
\text { ing children }\end{array}$ & $\begin{array}{l}\text { phonological } \\
\text { awareness test }\end{array}$ & Yes & $\begin{array}{l}\text { Mann-Whitney } \\
\text { and Kruskal- } \\
\text { Wallis }\end{array}$ & $\begin{array}{l}\text { Age of children had a } \\
\text { significant } \\
\text { influence on phonological } \\
\text { awareness, but there was } \\
\text { not any influence for sex. } \\
\text { Children with CI had } \\
\text { better function than } \\
\text { NH children in the area of } \\
\text { phonological awareness, } \\
\text { but there was no signifi- } \\
\text { cant difference between } \\
\text { the two groups. }\end{array}$ \\
\hline 8 & $\begin{array}{l}\text { Tavakoli } \\
\text { et al; } \\
2015(36)\end{array}$ & $\begin{array}{l}\text { Cross- } \\
\text { sectional } \\
\text { study }\end{array}$ & $\begin{array}{c}20 \mathrm{CI} \text { and } \\
20 \mathrm{NH}\end{array}$ & $\begin{array}{l}60-72 \\
\text { months }\end{array}$ & Yes & $\begin{array}{l}\text { Study of lan- } \\
\text { guage of CI } \\
\text { and normal hear- } \\
\text { ing children }\end{array}$ & $\begin{array}{l}\text { Action picture } \\
\text { stimuli: } \\
\text { analysis of } \\
\text { MLU, NDW, } \\
\text { and NTW }\end{array}$ & Yes & $\begin{array}{l}\text { Descriptive } \\
\text { statistics }\end{array}$ & $\begin{array}{l}\text { Children with CIs and } \\
\text { their normally developing } \\
\text { age-matched children } \\
\text { were significantly differ- } \\
\text { ent for all measures, } \\
\text { whereas there were no } \\
\text { differences between CI } \\
\text { children and their normal- } \\
\text { ly developing children } \\
\text { that matched based on } \\
\text { hearing age }\end{array}$ \\
\hline 9 & $\begin{array}{l}\text { Dasht et } \\
\text { al; } 2015 \\
\text { (37) }\end{array}$ & $\begin{array}{l}\text { Cross- } \\
\text { sectional } \\
\text { study }\end{array}$ & $\begin{array}{c}30 \mathrm{CI} \text { and } \\
30 \mathrm{NH}\end{array}$ & 6-11 years & NR & $\begin{array}{l}\text { Study of phone- } \\
\text { mic awareness of } \\
\text { CI } \\
\text { and normal hear- } \\
\text { ing children }\end{array}$ & $\begin{array}{l}\text { phonological } \\
\text { awareness test }\end{array}$ & Yes & t-test & $\begin{array}{l}\text { Children with CI had } \\
\text { lower } \\
\text { performance in phonemic } \\
\text { awareness than normal- } \\
\text { hearing children }\end{array}$ \\
\hline 10 & $\begin{array}{l}\text { Soleyman } \\
\text { i et al; } \\
2016(38)\end{array}$ & $\begin{array}{c}\text { Cross- } \\
\text { sectional } \\
\text { study }\end{array}$ & $\begin{array}{c}18 \mathrm{CI} \text { and } \\
18 \mathrm{NH}\end{array}$ & $\begin{array}{c}5.0-5.5 \\
\text { years }\end{array}$ & Yes & $\begin{array}{l}\text { Comparison of } \\
\text { language and } \\
\text { phonological } \\
\text { awareness skills } \\
\text { between CI } \\
\text { and normal hear- } \\
\text { ing children }\end{array}$ & $\begin{array}{l}\text { Test of } \\
\text { Language } \\
\text { Development- } \\
\text { Primary, third } \\
\text { edition \& } \\
\text { phonological } \\
\text { awareness } \\
\text { (PA) }\end{array}$ & Yes & $\begin{array}{l}\text { Kolmogorov- } \\
\text { Smirnov com- } \\
\text { parison \& } \\
\text { t-test \& } \\
\text { Pearson's corre- } \\
\text { lation } \\
\text { Coefficient }\end{array}$ & $\begin{array}{l}\text { Children with NH and CI } \\
\text { had significant differ- } \\
\text { ences in language skills } \\
\text { and phonological aware- } \\
\text { ness. Different skills of } \\
\text { language including se- } \\
\text { mantics, syntax, listening, } \\
\text { spoken language, organ- } \\
\text { izing, and speaking } \\
\text { Predicted phonological } \\
\text { awareness result. }\end{array}$ \\
\hline
\end{tabular}


S. Khoramian, et al.

\begin{tabular}{|c|c|c|c|c|c|c|c|c|c|c|}
\hline & Study & Design & $\begin{array}{l}\text { Population/ } \\
\text { Sample } \\
\text { size (n) }\end{array}$ & Age & $\begin{array}{l}\text { Randomiza- } \\
\text { tion }\end{array}$ & $\begin{array}{c}\text { Target } \\
\text { (What studied) }\end{array}$ & $\begin{array}{c}\text { Data } \\
\text { collection }\end{array}$ & $\begin{array}{c}\text { Validity and } \\
\text { reliability } \\
\text { stated }\end{array}$ & $\begin{array}{c}\text { Statistical } \\
\text { analysis } \\
\text { explained }\end{array}$ & Results \\
\hline 11 & $\begin{array}{c}\text { Rezaei et } \\
\text { al; } \\
2016 \\
(39)\end{array}$ & $\begin{array}{l}\text { Cross- } \\
\text { sectional } \\
\text { study }\end{array}$ & $\begin{array}{l}24 \mathrm{CI} \\
24 \mathrm{HA} \\
24 \mathrm{NH}\end{array}$ & $\begin{array}{l}\text { Second } \\
\text { and the } \\
\text { third } \\
\text { grades of } \\
\text { elemen- } \\
\text { tary } \\
\end{array}$ & NR & $\begin{array}{l}\text { Study of reading } \\
\text { skills between CI } \\
\text { and normal hearing } \\
\text { children in second } \\
\text { and third grade } \\
\text { elementary }\end{array}$ & $\begin{array}{l}\text { NAMA } \\
\text { reading test }\end{array}$ & Yes & $\begin{array}{c}\text { T-test, linear } \\
\text { regression and } \\
\text { Pearson correla- } \\
\text { tions }\end{array}$ & $\begin{array}{l}\text { Normal children have } \\
\text { better performance } \\
\text { than CI in reading } \\
\text { skills }\end{array}$ \\
\hline 12 & $\begin{array}{l}\text { Aminra- } \\
\text { souli et } \\
\text { al; } 2017 \\
(40)\end{array}$ & $\begin{array}{l}\text { Cross- } \\
\text { sectional } \\
\text { study }\end{array}$ & $\begin{array}{l}20 \mathrm{CI} \\
20 \mathrm{NH}\end{array}$ & $\begin{array}{l}4 \text { to } 6 \\
\text { years }\end{array}$ & NR & $\begin{array}{l}\text { A comparison } \\
\text { phonological pro- } \\
\text { cessing and sentence } \\
\text { comprehension of } \\
\text { cochlear } \\
\text { implant and normal } \\
\text { hearing children }\end{array}$ & $\begin{array}{l}\text { - Non-Word } \\
\text { Repetition } \\
\text { (NWR) task } \\
-\quad \text { Persian } \\
\text { Syntax } \\
\text { Comprehen- } \\
\text { sion Test } \\
\text { (PSCT); } \\
\text { - Persian } \\
\text { version of } \\
\text { TOLD-P: } 3\end{array}$ & $\begin{array}{l}- \text { Yes } \\
- \text { Yes } \\
\text {-Yes }\end{array}$ & $\begin{array}{c}\text { T-test } \\
\text { Pearson } \\
\text { correlation }\end{array}$ & $\begin{array}{l}\text { children with CIs } \\
\text { may experience } \\
\text { difficulties in phono- } \\
\text { logical processing } \\
\text { and } \\
\text { Sentence comprehen- } \\
\text { sion. In children with } \\
\text { CIs, with increasing } \\
\text { their experience in } \\
\text { processing of sound, } \\
\text { sentence comprehen- } \\
\text { sion skills improved. } \\
\text { There is a relation- } \\
\text { ship between the } \\
\text { NWR and sentence } \\
\text { comprehension. }\end{array}$ \\
\hline 13 & $\begin{array}{l}\text { Zamani } \\
\text { et al; } \\
2018(41)\end{array}$ & $\begin{array}{l}\text { Cross- } \\
\text { sectional } \\
\text { study }\end{array}$ & $\begin{array}{l}54 \mathrm{CI} \\
60 \mathrm{HA} \\
60 \mathrm{NH}\end{array}$ & $\begin{array}{l}10-13 \\
\text { years }\end{array}$ & NR & $\begin{array}{l}\text { A comparison Spo- } \\
\text { ken and Written } \\
\text { Narrative of cochlear } \\
\text { implant and Hearing } \\
\text { Aid and normal } \\
\text { hearing children }\end{array}$ & $\begin{array}{l}\text { a pictorial } \\
\text { story (The } \\
\text { Playful } \\
\text { Little Ele- } \\
\text { phant) }\end{array}$ & Yes & $\begin{array}{c}\text {-ANOVA } \\
\text {-repeated } \\
\text { measures } \\
\text { ANOVA } \\
\text {-Bonferroni } \\
\text { adjustment test }\end{array}$ & $\begin{array}{l}\text { Students with hearing } \\
\text { impairments had } \\
\text { significantly lower } \\
\text { scores in all of the } \\
\text { microstructure com- } \\
\text { ponents of narratives } \\
\text { than normal hearing. } \\
\text { No significant differ- } \\
\text { ence found among } \\
\text { different groups in } \\
\text { macrostructure com- } \\
\text { ponents of narratives. }\end{array}$ \\
\hline 14 & $\begin{array}{l}\text { Golesta- } \\
\text { ni et al; } \\
2018(42)\end{array}$ & $\begin{array}{l}\text { Cross- } \\
\text { sectional } \\
\text { study }\end{array}$ & $\begin{array}{l}22 \mathrm{CI} \\
11 \mathrm{NH}\end{array}$ & 5 years & NR & $\begin{array}{l}\text { Morpho-syntactic } \\
\text { skills in CI children } \\
\text { and children with NH } \\
\text { were compared }\end{array}$ & $\begin{array}{l}\text { Language } \\
\text { samples } \\
\text { analysis } \\
\text { (via; PDSS) }\end{array}$ & Yes & $\begin{array}{l}\text { Mann-Whitney } \\
\text { U test were }\end{array}$ & $\begin{array}{l}\text { Children with CIs } \\
\text { probably exhibit poor } \\
\text { abilities for using } \\
\text { complex sentences } \\
\text { and essential mor- } \\
\text { phology items. }\end{array}$ \\
\hline
\end{tabular}

\section{Results}

All articles were cross-sectional with sample size range 20 to174 subjects. The participants in the examination group were the children with CI, and those in the control group were their peers with normal hearing or children with hearing aid. Participants were aged 5-13 year old. Random sampling method was used by four articles (32, $34,36,38)$.

The language components studied in these articles were as follows; three articles studied the language as a single concept $(30,32,38)$. Four articles focused on phonology (phonology awareness skills) $(29,34,35,38)$. Another four articles concentrated on grammatical skills (understanding and expressing passive verbs and MLU (mean length of utterance) indices, morpho-syntactic abilities and sentence comprehension) as well as some semantic skills (NDW (number of different words)/NTW (number of total words) indices and TTR (Type-Token Ratio)) (31, 36, 40, 42). One article reviewed spoken and written narrative abilities (41) and two studies check out reading skills (33, 39).

Overall, studies that examined the language as a single concept, argued that the language skills of children with
$\mathrm{CI}$ are significantly lower than $\mathrm{NH}$ children $(30,32,38)$. However, the language skill scores of these children are in the normal range, which indicates an acceptable level of language (38) Phonological skills studies show that children with CI in all phonological awareness abilities, including phonemic blending, recognizing words with the same initial phonemes, naming and deletion the final phoneme and recognizing words with the same final phoneme, are weaker than $\mathrm{NH}$ children $(29,34,35,37,38)$. One study reported that children with CI in visual stimuli perform better than visual-auditory stimuli (34). MLU in children with $\mathrm{CI}$ and $\mathrm{NH}$ children is not significantly different (36). When the level of the vocabulary is higher, the child will have better performance in the syntax (36). Another study in this area indicates that the understanding and expression "passive verb" in CI children is considerably weaker than NH children (31). The results of the study of sentence comprehension skills suggest that children with CI have phonological processing and sentence comprehension impairments, but by improving the experience in sound processing, the sentence comprehension improves (40). A study for the morpho-syntactic skills of these children showed that children are able to express simple structure, but in using complex structures, they 
have poor skills, especially in morphology (42).A study that examined some of the semantic skills mentioned that among indicators NTW, NDW, and TTR, all indices except TTR were better in normal children, but there was no significant difference (36). This indicates the appropriate level of vocabulary in CI children. And finally, studies that examined children with CI's reading skills reported that the performance of normal children was better than CI children reading skills. Both studies showed that the reading skills of nonwords in CI children with $\mathrm{NH}$ children were not significantly different $(33,39)$. A study that examined the narrative skills of these children announced that CIs had significantly lower scores in all of the microstructure components of narratives, but no significant difference was found in macrostructure components of narratives between CIs and normal children (41). One of these studies represented that although word and non-word reading and word comprehension skills are similar in children with CI and hearing aid, text comprehension is better in CI children (39).

The final 14 articles were examined using the Grades recommendations, assessment, development, and evaluation (GRADE) (27), which is designed to score the general quality of the evidences of each finding. From GRADE point of view, judge quality of evidences including study design, study quality, consistency, and accuracy.

\section{Study design}

According to GRADE, studies can be categorized into two general categories of clinical trial and observation studies. The articles under study here were all observational and cross-sectional.

\section{Study quality}

Ten metrics including random study, control group, computation factor, blindness of study, clear inclusion criteria, complete results report, sample size, and parameters of research tool (e.g., validity, reliability, and normality) were taken into account. Table 2 shows the scores of quality and evidence levels for the articles included in the present study.

To evaluate the articles, we used the Cochran's guideline, and it was assessed based on the Grading of Recommendations Assessment, Development, and Evaluation (GRADE) methods.

Computation factors of Cochran's guideline were used, in which the factors are a function of the following elements:

- Definition of measurement (method of diagnosis, name of scale, definition of limits, and type of behavior);

- Time schedule;

- Scale (upper/lower limits and if the upper/lower score is suitable); and

- Measurement unit.

Table 2. The scores of quality and evidence levels for included studies

\begin{tabular}{|c|c|c|c|c|c|c|c|c|c|c|c|c|}
\hline Author & 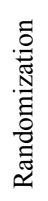 & $\begin{array}{l}\overrightarrow{0} \\
\text { : } \\
0\end{array}$ & 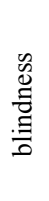 & $\begin{array}{l}\text { Outcome } \\
\text { measure } \\
\text { reporting }\end{array}$ & $\begin{array}{c}\text { Power } \\
\text { Calculation }\end{array}$ & $\begin{array}{c}\text { The sample size is } \\
\text { appropriate? }\end{array}$ & $\begin{array}{l}\text { Inclusion/ } \\
\text { exclusion } \\
\text { criteria } \\
\text { is clearly- } \\
\text { stated? }\end{array}$ & 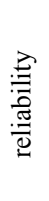 & : & 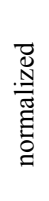 & 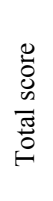 & $\begin{array}{c}\text { Level of } \\
\text { evidence1 }\end{array}$ \\
\hline $\begin{array}{l}\text { Weisi et al., } \\
2012 \text { (33) }\end{array}$ & 0 & 2 & 0 & 1 & 0 & 2 & 0 & 2 & 2 & 0 & 9 & Low \\
\hline $\begin{array}{l}\text { Rahimi et al., } 2013 \\
(30)\end{array}$ & 0 & 2 & 0 & 1 & 0 & 2 & 2 & 2 & 2 & 2 & 13 & Moderate \\
\hline $\begin{array}{l}\text { Weisi et al., } \\
\text { 2013(29) }\end{array}$ & 0 & 2 & 0 & 1 & 0 & 2 & 0 & 2 & 2 & 0 & 9 & Low \\
\hline $\begin{array}{l}\text { Mahmoodabadi } \\
\text { et al., } 2013 \text { (34) }\end{array}$ & 1 & 2 & 0 & 1 & 0 & 1 & 2 & 2 & 2 & 2 & 13 & Moderate \\
\hline $\begin{array}{l}\text { Rastegarianzadeh et } \\
\text { al } 2014(35)\end{array}$ & 0 & 2 & 0 & 1 & 0 & 1 & 1 & 2 & 2 & 2 & 11 & Low \\
\hline $\begin{array}{l}\text { Ghaemi et al., } \\
2014(31)\end{array}$ & 0 & 2 & 0 & 1 & 0 & 2 & 1 & 1 & 1 & 1 & 8 & Low \\
\hline $\begin{array}{l}\text { Mohseni et al., } 2015 \\
\text { (32) }\end{array}$ & 2 & 2 & 0 & 1 & 0 & 2 & 2 & 2 & 2 & 0 & 13 & Moderate \\
\hline $\begin{array}{l}\text { Tavakoli } \\
\text { et al; } 2015(36)\end{array}$ & 1 & 2 & 0 & 1 & 0 & 2 & 1 & 2 & 2 & $2^{*}$ & 13 & Moderate \\
\hline $\begin{array}{l}\text { Dashtelei ; } \\
2015(36)\end{array}$ & 0 & 2 & 0 & 1 & 0 & 2 & 1 & 2 & 2 & 2 & 12 & Moderate \\
\hline $\begin{array}{l}\text { soleymanis' et al; } \\
2016(38)\end{array}$ & 1 & 2 & 0 & 1 & 0 & 1 & 2 & 2 & 2 & 2 & 13 & Moderate \\
\hline $\begin{array}{l}\text { Rezaei } \\
2016(39)\end{array}$ & 0 & 2 & 0 & 1 & 0 & 2 & 1 & 2 & 2 & 0 & 10 & Low \\
\hline $\begin{array}{l}\text { Aminrasouli } 2017 \\
(40)\end{array}$ & 0 & 2 & 0 & 1 & 0 & 2 & 2 & 2 & 2 & 2 & 13 & Moderate \\
\hline $\begin{array}{l}\text { Zamani et al; } 2018 \\
\text { (41) }\end{array}$ & 0 & 2 & 0 & 2 & 0 & 2 & 2 & 2 & 2 & 0 & 12 & Moderate \\
\hline $\begin{array}{l}\text { Golestani et al; } 2018 \\
\text { (42) }\end{array}$ & 0 & 2 & 0 & 1 & 0 & 2 & 2 & 2 & 2 & $2^{*}$ & 13 & Moderate \\
\hline
\end{tabular}


The results of the measurements and surveys are summarized in Table 2 base on the study's quality score. As listed, none of the articles are categorized at a high level based on the GRADE metrics and only four papers had an average level.

\section{Consistency of study}

From GRADE point of view, consistency is related to statistical heterogeneity, contradictory results, inconsistency with other studies, and inconsistent results. According to GRADE and PRISMA, consistency is measured for meta-analysis studies, and since the articles in this study were different in terms of sample size, objectives, and language fields under study and thus considered as heterogenic studies, it was not possible to perform a meta-analysis. Given the fact that each of our studies looked at one of the linguistic areas; the data from these studies did not allow aggregation and meta-analysis.

As seen in Table 2, all studies except one of them used a valid and reliable tests or indicators, all of them had control group, most of them (11 out of 14 studies) had appropriate sample size, Half of them (7 out of 14 studies) clearly stated their inclusion/ exclusion criteria. None of the studies reported blindness or power calculation. Altogether the quality of all studies, based on GRADE, was graded as moderate and low (According to Table 2).

\section{Study accuracy}

The accuracy of the study depends on the factors influencing the bias of the study, such as the skill of the view- er, blindness, some aspects of test accuracy, and some aspects of measurement (e.g., confidence interval, p-value, and effective size) are effective on the accuracy of the test. Publication bias analysis was not applied here due to the limited number of qualifying studies. Table 3 shows test $\&$ measurement features for included articles. Summary of the results are presented in Table 4.

All tests used in the articles were reliable except for one test used by Ghaemi (expression of passive verbs) (31). The rest of the tests were also valid. In terms of normality and cut point only one test in phonological awareness field $(29,34,37,38)$, one test on the perception of passive verbs $(31)$ and TOLD test $(30,38,40)$ met the required condition.

All the articles used expert viewer, which is a strong point for all of them. With regard to measurement indices, all the articles but one (29) mentioned p-value to determine the significance of the results and only one study calculated the effect size (41); however, none of them mentioned confident interval. Randomized grouping of the test and control groups was only done by Mohseni, randomized grouping of the control group was only done in two studies, and randomized grouping of the test group was only done by Tavakoli $(32,34,36,38)$.

\section{Discussion}

To obtain a clear picture of the Iranian studies on language development of children with $\mathrm{CI}$, that was our first goal, the selected articles were examined using relia-

Table 3. Test \& measurement features for included articles

\begin{tabular}{|c|c|c|c|c|c|c|c|c|c|}
\hline \multirow{3}{*}{ Author } & \multicolumn{3}{|c|}{ Test features } & & \multicolumn{5}{|c|}{ Measurement features } \\
\hline & Reliability & Validity & Normalized & Skill & $\mathrm{P}$ value & Confidence & Effect & $\mathrm{Ra}$ & mization \\
\hline & & & & examiner & stated & Interval & Size & $\begin{array}{l}\text { Control } \\
\text { Group }\end{array}$ & $\begin{array}{l}\text { Experimental } \\
\text { Group }\end{array}$ \\
\hline $\begin{array}{l}\text { Weisi et al., } \\
2012(33)\end{array}$ & Yes & Yes & No & Yes & Yes & NR & NR & No & No \\
\hline $\begin{array}{l}\text { Rahimi et al., } 2013 \\
\text { (30) }\end{array}$ & Yes & Yes & Yes & Yes & No & No & No & No & No \\
\hline $\begin{array}{l}\text { Weisi et al., } \\
2013(29)\end{array}$ & Yes & Yes & No & Yes & Yes & NR & NR & No & No \\
\hline $\begin{array}{l}\text { Mahmoodabadi } \\
\text { et al., } 2013 \text { (34) }\end{array}$ & Yes & Yes & Yes & Yes & Yes & NR & NR & Yes & No \\
\hline $\begin{array}{l}\text { Niloufar Rastegari- } \\
\text { anzadeh et al } 2014 \\
(35)\end{array}$ & Yes & Yes & Yes & Yes & Yes & NR & NR & No & No \\
\hline $\begin{array}{l}\text { Ghaemi et al., } \\
2014 \text { (31) }\end{array}$ & $\begin{array}{c}\text { Comprehension: } \\
\text { yes }\end{array}$ & Yes & Yes & Yes & Yes & NR & NR & No & No \\
\hline $\begin{array}{l}\text { Mohseni et al., } \\
2015 \text { (32) }\end{array}$ & $\begin{array}{c}\text { Expression: NR } \\
\text { Yes }\end{array}$ & $\begin{array}{l}\text { NR } \\
\text { Yes }\end{array}$ & $\begin{array}{l}\text { No } \\
\text { No }\end{array}$ & Yes & Yes & NR & NR & Yes & Yes \\
\hline $\begin{array}{l}\text { Tavakoli } \\
\text { et al; } 2015 \text { (36) }\end{array}$ & Yes & No & -- & Yes & Yes & NR & NR & No & Yes \\
\hline $\begin{array}{l}\text { Dashtelei ; } 2015 \\
\text { (37) }\end{array}$ & Yes & Yes & Yes & Yes & Yes & No & No & NR & NR \\
\hline $\begin{array}{l}\text { soleymanis' et al; } \\
2016(38)\end{array}$ & Yes & Yes & Yes & Yes & Yes & NR & NR & Yes & No \\
\hline $\begin{array}{l}\text { Rezaei } \\
2016(39)\end{array}$ & Yes & Yes & No & Yes & Yes & NR & NR & No & No \\
\hline $\begin{array}{l}\text { Aminrasouli et al; } \\
2017(40)\end{array}$ & Yes & Yes & Yes & Yes & Yes & NR & NR & NR & NR \\
\hline $\begin{array}{l}\text { Zamani et al; } 2018 \\
\text { (41) }\end{array}$ & Yes & Yes & No & Yes & Yes & Yes & yes & NR & NR \\
\hline $\begin{array}{l}\text { Golestani et al; } \\
2018 \text { (42) }\end{array}$ & Yes & Yes & ----- & Yes & Yes & No & No & NR & NR \\
\hline
\end{tabular}




\begin{tabular}{lcc}
\hline Table 4. The summary of the appraisal result & & \\
\hline measure & $\begin{array}{c}\text { Number of articles conveyed } \\
\text { this measure }\end{array}$ & $\begin{array}{c}\text { studies conveyed this measure as } \\
\text { numbered in Table } 1 *\end{array}$ \\
\hline Sufficient sample size & 11 out of 14 & $\begin{array}{c}\text { All studies } \\
\text { Except } 4,5 \text { and } 10 \\
\text { Randomization }\end{array}$ \\
blindness & 4 out of 14 & $4,7,8,10$ \\
Power & 0 & - \\
Calculation & 0 & - \\
Control & 14 out of 14 & All studies \\
Skill examiner & 14 out of 14 & All studies \\
Validity & 14 out of 14 & All studies \\
Reliability & 14 out of 14 & All studies
\end{tabular}

ble critical appraisal forms. The review showed that the studies on Persian speaking children with CI were observational study, based on the classification introduced by Greenhalgh in "how to read a paper," (43). Given this and to enrich basic and clinical knowledge in this field, the future studies need to adopt higher levels of study design such as a clinical trial.

Despite the high prevalence of hearing impairments and the fact that CI operations have been carried out for two decades in Iran, there is a paucity of studies on Persian language and most of the studies in this field are acoustic and vocal studies that rely on laboratory voice recording devices and software analysis (e.g., Praat) (22-25). A serious limitation for studies on Persian speaking children with CI is the lack of normalized verbal tests in different fields of language. Pragmatics was an absent element in all articles under study, and there are uncapped subgroups such as grammar, semantics, and morphology, and many aspects of reading and writing skills. Studying different aspect of language in children with CI deepens on clinical knowledge of therapists, facilitates, and efficient medical interventions.

Despite the fact that most research on language in the world is done using standard tests, as noted earlier, most of the tests used in Persian language studies were valid and reliable, except for three tests including morphology awareness, assessment of passive verbs perception, and TOLD test - each focused on a specific field of language none of the tests was normalized or had cut point. Lack of normalized tests is one of the limitations of studies in Persian language, and there is a need for developing more tests in the different fields of language in Persian. In spite of these deficiencies, studies in the language field tried to use valid and reliable tests. These studies showed that the language score of children with CI is generally low, but is in the natural domain. Children with CI performed lower than normal in language components such as phonological awareness, word reading, text and sentence comprehension, the expression and perception of passive verbs and complex structure, but these two groups of children had no significant difference in TTR, MLU indices, nonword reading and macrostructure components of narratives. A review of these studies has shown that cochlear implantation is effective for the language development of sensorineural hearing-impaired Persian speakers, like the whole world.

Our other goal was to evaluate the quality of the articles and to do so, we used the quality review questionnaires.
Quality examinations showed that the issues such as negligence of blindness, failure to obtain test power, failure to randomize, failure to report the whole measurement process, and failure to use normalized tests decreased the quality score of the articles. Blindness was not a priority for the authors, as the studies were not observational. The reason for failure to select the participant randomly is lack of a patients' databank in Iran and lack of access to the patients; so that many authors adopt convenient sampling method instead. Availability of patients' databank improves quality and quantity to studies. In addition, more standard tests are needed to improve the quality of Persian studies. However, one of the strengths of Persian studies is to be committed to using valid and reliable tests. Another one is the use of indicators such as MLU, NTW, NDW and PDSS (Persian developmental sentence scoring), which examines the spontaneous speech of children and those that cannot be measurable in the standard tests. In the report section of the study results, only p-value had been reported by the articles, while this metric only determines if there is a significant difference between the two groups $(44,45)$. Reporting confidence interval enables the reader to estimate the actual amount of difference between the groups; however, none of the articles reported this metric. Confidence interval also indicates if repeating the study with a larger sample group is clinically valid (46). Moreover, the effect size is another metric that covers shortages of the sample size and makes it possible to use the study for systemic review and meta-analysis; this index can also be a start point for studies with larger sample groups (47). We could not perform a meta-analysis because there was not enough information in literature to do that.

Another objective of the study was to determine the fields of language examined or neglected by the studies on Persian speaking children with CI. The articles examined language as a unified concept or different components of language, such as phonology awareness, grammar, and reading skills. Many other fields of language such as pragmatics, semantics and several subcategories of grammar have not been studied in Persian speaking children with CI yet. It is recommended that these areas be considered in future studies.

One of the most important limitations of this study was the small number of available articles; it was not possible to carry out a meta-analysis because of the small number of studies and high diversity of data and specifications of subject groups. Increase in the number of research works 
might give us a better chance to carry out systemic review and meta-analysis studies in the future.

A cochlear implant is an advanced technology that has helped the hearing impaired all over the world to acquire language. This technology is progressing every day, and its use expands in the world. The results of this study can be used in linguistic studies of countries that have recently come to this technology. The outcomes of this study lead to language studies to pay attention to all aspects of language, such as pragmatics and semantic. In addition, it reminds us that it will increase the quality of the articles, such as taking random sampling, blindness of the study, expressing the confidence interval and the effect size, etc.

A summary of the quality of the articles based on GRADE's critical form is as follows: The articles were all observational and cross-sectional in terms of design. From the point of view of quality scores, all papers were ranked low and medium. In terms of consistency, our studies were heterogeneous, as stated in the results. From the accuracy point of view, studies were at moderate levels, although the tests that were used were not standard, they were valid and reliable. In the result measurements, the skilled examiner was used, the $\mathrm{P}$ value was reported, but the confidence interval and effect size were not reported. In spite of all the limitations that have been identified in the Persian language for researching the language of children with CI, research had much strength that could be cited as follows; the assessment was conducted by expert staff in all studies. Almost all studies were committed to valid and reliable tests, and they had a good sample size. These strengths have caused most GRADE grading studies ( 9 out of 14 studies) are on a moderate level, and no studies at the level are very low.

Common standard tools are in English language. While providing a standard tool has become popular in recent years to language tests in Iran, the number of Persian tests is still very low. In English, there are different types of studies such as longitudinal, experimental and case study design $(48,49)$, but in Persian, major studies are crosssectional, and there are fewer studies of the other type. In all aspects of language such as semantics, pragmatics, and morphology, the study is conducted in English (50-53). Of course, most of these differences are due to the widespread use of English language and a longer history of cochlear implantation in English-speaking countries, and it seems that the study of Persian is also progressively expanding.

\section{Conclusion}

Cochlear implantation in language acquisition is very effective in Persian-speaking children with hearing impairment. Some aspects of language such as pragmatics and semantics have not been considered in studies that are helpful in improving treatment. The results of the present study showed that we need to develop standard language tests in the Persian language for accurate assessment and comparison of children in different language component (Such as the standard tests of vocabulary, semantics, phonology, syntax, morphology, and pragmatic assessment). This review demonstrates that there is the necessity for further in-depth studies, with the aim of standardizing the assessment tools in order to provide clarity of language development children with CIs. Using these tools increases the accuracy of the information on children and improves quality of the treatment and rehabilitation. The existence of such tools will lead to more extensive and credible studies on these children. There is also a need for more studies with stronger statistical ground which have computations such as the confidence interval and the effect size. Using accurate statistics will increase the validity of the study. Finally, development of a patients' databank facilitates wider, deeper, and more accurate studies on a larger group of participants.

\section{Conflict of Interests}

The authors declare that they have no competing interests.

\section{References}

1. Farhat AS, Ghasemi MM, Akhondian J, Mohamadzadeh A, Esmaeili $\mathrm{H}$, Amiri R, et al. Assessment of the Prevalence of Hearing Impairment in Neonates Born in Imam Reza, Ghaem and OMAlbanin Hospitals of Mashhad. Mashhad Uni Med Sci. 2014 Jul $1 ; 5(2): 17-20$

2. Zarandy MM, Malekpour M. Two cochlear implants: halving the number of recipients. Lancet (London, England). 2007 Nov 17;370(9600):1686

3. Masataka N. Advances in the Spoken Language Development of Deaf and Hard-of-Hearing Children. Spencer PE, Marschark M, editors. Advances in the Spoken Language Development of Deaf and Hard-of-Hearing Children. Oxford University Press; 2005. 42-66 p.

4. Kronenberger WG, Pisoni DB. Profiles of Verbal Working Memory Growth Predict Speech and Language Development in Children with Cochlear Implants. J Speech Lang Res. 2013;56(3):805-25.

5. May-Mederake B. Early intervention and assessment of speech and language development in young children with cochlear implants. Int J Pediatr Otorhinolaryngol. 2012;76(7):939-46.

6. Ross DS, Holstrum WJ, Gaffney M, Green D, Oyler RF, Gravel JS. Hearing screening and diagnostic evaluation of children with unilateral and mild bilateral hearing loss. Trends Amplif. 2008 Mar;12(1):27-34

7. Abdollahi Fakhim Sh, Nazari MR. Determintion of Frequency and Causes of Hearing Loss in High Risk Neonates in Tabriz. Otolaryngology. 2007;29(3):77-82.

8. Leybaert J, LaSasso CJ. Cued speech for enhancing speech perception and first language development of children with cochlear implants. Trends Amplif. 2010;14(2):96-112.

9. Blamey PJ, Sarant JZ, Paatsch LE, Barry JG, Bow CP, Wales RJ, et al. Relationships among speech perception, production, language, hearing loss, and age in children with impaired hearing. J Speech Lang Hear Res. 2001;44(2):264-85.

10. Boothroyd A, Geers AE, Moog JS. Practical implications of cochlear implants in children. Ear Hear. 1991;12(4 SUPPL.):81S$89 \mathrm{~S}$.

11. Cleary M, Pisoni DB, Geers AE. Some measures of verbal and spatial working memory in eight- and nine-year-old hearingimpaired children with cochlear implants. Ear Hear. 2001 Oct;22(5):395-411.

12. Geers A, Moog J. Spoken Language Results: Vocabulary, Syntax, and Communication., Volta Review, 1994. Volta Rev. 1994;96(5):131-48.

13. Geers AE, Nicholas JG, Sedey AL. Language skills of children with early cochlear implantation. Ear Hear. 2003;24(1 Suppl):46S-58S.

14. Geers AE. Factors affecting the development of speech, language, and literacy in children with early cochlear implantation. Lang Speech Hear Serv Sch. 2002 Jul 1;33(3):172-183.

15. Owens RE, Dehn MJ, Issues T, Implications C, Haresabadi F, Ebadi A, et al. Working Memory and Academic Learning: Assessment and Intervention. Child Lang Teach Ther. 2016;32:193-204.

16. Paul R, Norbury C. Language disorders from infancy through 
adolescence: listening, speaking, reading, writing, and communicating. Elsevier; 2012. 756 p.

17. Oryadi Zanjani MM, Hasanzadeh S, Rahgozar M, Shemshadi H, Purdy SC, Mahmudi Bakhtiari B, et al. Comparing the effect of auditory-only and auditory-visual modes in two groups of Persian children using cochlear implants: A randomized clinical trial. Int J Pediatr Otorhinolaryngol. 2013;77(9):1545-50.

18. Hashemi SB, Rajaeefard A, Norouzpour H, Tabatabaee HR, Monshizadeh L. The Effect of Cochlear Implantation on the Improvement of the Auditory Performance in 2-7 Years old Children, Shiraz 2004-2008. Iran Red Crescent Med J. 2013 Mar;15(3):223-8.

19. Jeddi Z, Jafari Z, Motasaddi Zarandi M. The impact of cochlear implants and aural rehbilitaion program on auditory skills of children with cochlear implant. J Rehabil. 2013;14:67-75.

20. Manouchehri N, Adel Ghahraman M, Mobedshahi F, Motesadi Zarandi M, Rovshan B. Improvement of speech perception in children with cochlear implant. Bimon Audiol - Tehran Uni Med Sci. 2011;20(2):30-7.

21. Poursoroush S, Ghorbani A, Soleymani Z, Kamali M, Yousefi N, Poursoroush Z. Speech Intelligibility of Cochlear-Implanted and Normal-Hearing Children. Iran J Otorhinolaryngol. 2015 Sep;27(82):361-7.

22. Zamani P, Rahmanirasa A, Weisi F, Valadbeigi A, Farahani F, Rezaei M. Vowel Production in Persian Deaf Children with Cochlear Implant: is the Age of Implantation an Important Factor? Indian J Otolaryngol Head Neck Surg. 2014 Dec;66(4):407-13.

23. kord N, Shahbodaghi Mohammad R, Khodami SM, Nourbakhsh M, Jalaie S, Zarandy MM. Auditory and vestibular research. Audit Vestib Res. 2012;21(2):50-6.

24. Kord N, Shahbodaghi MR, Khodami SM, Nourbakhsh M, Jalaei S. Investigation of acoustic correlation of intonation and intelligibility of speech in children with cochlear implant and comparison with normal hearing children. J Mod Rehabil. 2013;6(4):38-43.

25. Kord N, Shahbodaghi MR, Khodami SM, Norbakhash M, Jalaei S, Motesadi Zarand M. Investigation of perception of intonation in primary school ages cochlear implant children and comparison with normal hearing children. J Mod Rehabil. 2010;4(3):1-5.

26. Moher D, Liberati A, Tetzlaff J, Altman DG, Group TP. Preferred Reporting Items for Systematic Reviews and Meta-Analyses: The PRISMA Statement. PLoS Med. 2009 Jul 21;6(7):e1000097.

27. Atkins D, Best D, Briss PA, Eccles M, Falck-Ytter Y, Flottorp S, et al. Grading quality of evidence and strength of recommendations. BMJ. 2004 Jun 19;328(7454):1490.

28. McGinn T, Wyer PC, Newman TB, Keitz S, Leipzig R. Tips for learners of evidence-based medicine: 3. Measures of observer variability (kappa statistic). CMAJ. 2004 Nov 23;171(11):1369-73.

29. Weisi F, Rezaei M, Lotfi G, Valadbeigi A. Comparison of phonological awareness between children with cochlear implants and children with hearing aids. Pajouhan Sci J .2013;11(2):35-8.

30. Rahimi M, Sadighi F, Razeghi S. A comparison of linguistic skills between persian cochlear implant and normal hearing children. Iran Rehabil J. 2013;11(17):11-9.

31. Ghaemi H, Vafaeian A, Chahkandi A, Sobhani Rad D, Riassi M, Tayrani H. The comparative study of comprehension and expression of passive verbs in children with hearing loss with cochlear implant and normal children. Mashhad Uni Med Siences. 2013 Sep 23;2(2):13-9.

32. Mohseni Ezhiyeh A, Faramarzi S, Abtahi S, Sepehrnejad M, Nilforoush M. Investigating and comparing language development of cochlear implanted children and children with normal hearing. J Res Rehabil Sci. 2015;1(2):92-7.

33. Weisi F, Rezaei M, Rashedi V, Heidari A, valadbeigi A, EbrahimiPour M. Comparison of reading skills between children with cochlear implants and children with typical hearing in Iran. Int $\mathrm{J}$ Pediatr Otorhinolaryngol. 2013 Aug;77(8):1317-21.

34. Mahmoodabadi N, Soleymani Z, Khodami M, Ajalloeian M, Jlaei S. A comparative study of performance of normal and cochlear implanted children in two phonological awareness tests. Sabzevar Univ Med Sci. 2014 Jan 1;20(4):547-55.

35. Rastegarianzadeh N, Shahbodaghi M, Faghihzadeh S. Study of phonological awareness of preschool and school aged children with cochlear implant and normal hearing. Korean J Audiol. 2014 Sep;18(2):50-3.

36. Tavakoli M, Jalilevand N, Kamali M, Modarresi Y, Zarandy MM.
Language sampling for children with and without cochlear implant: MLU, NDW, and NTW. Int J Pediatr Otorhinolaryngol. 2015 Dec;79(12):2191-5.

37. Dashtelei A, Mowzooni H, Ashtari A, Delfi M, Movallali G, Salmani A, et al. The phonemic awareness skills of cochlear implant children and children with normal hearing in primary school. Iran Rehabil J. 2015 Dec 15;13(4):90-4.

38. Soleymani Z, Mahmoodabadi N, Nouri MM. Language skills and phonological awareness in children with cochlear implants and normal hearing. Int J Pediatr Otorhinolaryngol. 2016;83:16-21.

39. Rezaei M, Rashedi V, Morasae EK, Khedmati E. Reading skills in Persian deaf children with cochlear implants and hearing aids. Int $\mathrm{J}$ Pediatr Otorhinolaryngol. 2016;89:1-5.

40. Aminrasouli N, Mohamadi R, Jenabi MS, Kamali M. A Comparison Phonological Processing and Sentence Comprehension of Cochlear Implant and Normal Hearing Children. 2018;1(1):1-8.

41. Zamani P, Soleymani Z, Rashedi V, Farahani F, Lotfi G, Rezaei M. Spoken and Written Narrative in Persian-Speaking Students Who Received Cochlear Implant and / or Hearing Aid. Clin Exp Otorhinolaryngol. 2018 Dec;11(4):250-258.

42. Dehghani S, Jalilevand N, Kamali M. A comparison of morphosyntactic abilities in deaf children with cochlear implant and 5-yearold normal-hearing children. Int $\mathrm{J}$ Pediatr Otorhinolaryngol. 2018;110(February):27-30.

43. Greenhalgh T. How to read a paper: the basics of evidence-based medicine. Wiley-Blackwell; 2010. 238 p.

44. Gallagher EJ. No proof of a difference is not equivalent to proof of no difference. J Emerg Med. 1994 Jul 1;12(4):525-7.

45. DIAMOND GA. Clinical Trials and Statistical Verdicts: Probable Grounds for Appeal. Ann Intern Med. 1983 Mar 1;98(3):385.

46. Gardner MJ, Altman DG. Statistics in Medicine Confidence intervals rather than $\mathrm{P}$ values: estimation rather than hypothesis testing. Br Med J. 1986;292.

47. Jones SR, Carley S, Harrison M. An introduction to power and sample size estimation. Emerg Med J. 2003 Sep 1;20(5):453-8.

48. Encinas D, Plante E. Feasibility of a Recasting and Auditory Bombardment Treatment With Young Cochlear Implant Users. Lang Speech Hear Serv Sch. 2016;47(2):157-70.

49. Dunn CC, Walker EA, Oleson J, Kenworthy M, Van Voorst T, Tomblin JB, et al. Longitudinal speech perception and language performance in pediatric cochlear implant users: the effect of age at implantation. Ear Hear. 2014;35(2):148-60.

50. Boons T, De Raeve L, Langereis M, Peeraer L, Wouters J, van Wieringen A. Expressive vocabulary, morphology, syntax and narrative skills in profoundly deaf children after early cochlear implantation. Res Dev Disabil. 2013 Jun 1;34(6):2008-22.

51. Rinaldi P, Baruffaldi F, Burdo S, Caselli MC. Linguistic and pragmatic skills in toddlers with cochlear implant. Int J Lang Commun Disord. 2013 Nov;48(6):715-25.

52. Most T, Shina-August E, Meilijson S. Pragmatic Abilities of Children With Hearing Loss Using Cochlear Implants or Hearing Aids Compared to Hearing Children. J Deaf Stud Deaf Educ. 2010 Oct $1 ; 15(4): 422-37$.

53. Toe DM, Paatsch LE. The conversational skills of school-aged children with cochlear implants. Cochlear Implants Int. 2013 Mar 18;14(2):67-79. 